\title{
The impact of pre-sale and post-sale factors on online purchasing satisfaction: a survey
}

\author{
Lucía Melián Alzola and Víctor Padrón Robaina \\ University of Las Palmas de Gran Canaria, Las Palmas, Spain
}

\begin{abstract}
Purpose - This work seeks to contribute a series of reflections and conclusions in response to the following questions: what variables determine satisfaction in the pre-sale phase and post-sale phase of $\mathrm{B} 2 \mathrm{C}$ electronic commerce? How are the variables of the pre-sale phase related to those of the post-sale phase of B2C electronic commerce?

Design/methodology/approach - The authors develop a theoretical scale that includes the important variables of quality in the pre-sale and post-sale phases of B2C electronic commerce. After the empirical validation of the theoretical scale, we measure the impact of the pre-sale dimensions on the post-sale dimensions.

Findings - The results confirm the principal hypotheses of the study, that is to say, the dimensions of the pre-sale phase have a significant impact on the dimensions of the post-sale phase of B2C electronic commerce.

Research limitations/implications - This research shows that, in B2C electronic commerce, the organisation's actions in the pre-sale phase will, to a great extent, condition its actions in the post-sale phase.

Practical implications - This paper highlights the importance of high-performance in the pre-sale phase in order to achieve success.

Originality/value - This paper bridges a gap in the empirical works in the field of quality in electronic commerce by studying the importance and implications of the different phases in the electronic purchase.
\end{abstract}

Keywords Electronic commerce, Quality, Quality management, Sales, After sales service

Paper type Research paper

\section{Introduction}

Business-to-customer (B2C) electronic commerce generates a type of business-customer transaction that is very different from the traditional physical purchase. In effect, electronic transactions in $\mathrm{B} 2 \mathrm{C}$ electronic commerce constitute another way of interacting with customers and display two notable differential characteristics (Douglas et al., 2003; Constantinides, 2002; Bitner, 2001):

(1) the absence of the seller; and

(2) the absence of physical premises.

In the digital context, the functions of the sales staff, including welcoming, informing, advising and explaining to the customer, are performed by the interface and the tangible aspects of the physical encounter are replaced by the computer monitor in electronic transactions (Corbitt et al., 2003; Bitner, 2001; Douglas et al., 2003; O'Neill et al., 2001). The vast differences between the physical and electronic purchase justify

International Journal of Quality \& Reliability Management Vol. 27 No. 2,2010 pp. 121-137 (C) Emerald Group Publishing Limited DOI $10.1108 / 02656711011014267$
Received November 2008 Revised January 2009, September 2009 Accepted October 2009

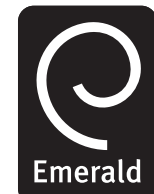
satisfaction \section{政}


IJQRM

27,2

122 the study of the phases, dimensions and factors that characterise electronic commerce $\mathrm{B} 2 \mathrm{C}$ and influence the overall quality perceived by the online customer, especially when the customer abandons the process in the early stages of the electronic purchase or when problems arise in the delivery stage or in the after-sales service. In the case of a mistake in the delivery of a product sold online, could it be that the information about the product was not sufficient and the customer did not know exactly what he/she was buying? Or that the information was complete but there were problems in selecting the logistics supplier and the online seller lacked control over that provider?

In order to analyse such aspects and to seek answers to these questions, the objectives of this research focus on the analysis of the content of each phase of B2C electronic commerce, and on the relationships between the key variables that define the different phases. In line with those objectives, the article begins with a study of the electronic purchase stages proposed in the relevant academic literature to the point where a proposal can be made that serves as a reference for this work. The next step is to define the relevant variables for each of the established phases and that will configure the theoretical scale to measure the quality for each phase. After the description of the principal characteristics of the fieldwork, we complete the research by establishing the relationships between the variables that define each phase, as well as their principal strategic and operational implications for firms selling on the internet.

\section{Phases of service encounters in B2C electronic commerce}

The review of the literature enabled us to obtain the different proposals for the stages of the electronic purchase: for example, Chen and Chang (2003) identify three phases. First, they distinguish a component or phase that they call "interactivity", which comprises the quality of the connection and the design of the website. They then identify the "transaction" phase, which covers issues such as value, convenience, security, entertainment and assessment. Their third phase, "fulfillment", addresses order processing, delivery and after-sales service.

From another approach, Cao and Gruca (2004) state that the online purchase has two clearly differentiated stages. The first is the pre-purchase stage, in which the customer navigates the website, makes a choice, takes a decision, makes the payment and is informed about delivery. The online vendor must design this part of the process satisfactorily so that the customer does not detect any errors or defects and consequently abandon the purchase. The issues to be considered in this stage are product selection, product information and the functioning of the website. Having completed this stage, the customer enters the post-purchase service provided by the online vendor; in other words, everything that occurs after closing the purchase. In this stage, the aspects regarding on-time delivery, order tracking, condition of product and customer support are evaluated.

According to Jiang and Rosenbloom (2005), the purchase process is divided into two subsystems: the subsystem of convenience and that of fulfilment. The first of those focuses on the pre-sale and transaction phases, in which the following issues are assessed:

- convenience and speed of the order process;

- quantity, quality and relevance of product information; 
- website functioning; and

- economic charges and delivery options.

The fulfilment subsystem includes the phases of order fulfilment and after-sales service, with the following aspects being measured:

- customer support;

- order tracking; and

- the match between the product description and what was really delivered.

Another noteworthy work is that of Parasuraman et al. (2005), who distinguish two stages in the online electronic purchase and develop a scale of quality for each of them. Thus, the E-S-QUAL scale aims to measure the quality of the principal or core service of the firm. The dimensions of quality for the principal service coincide with the criteria that customers use when they assess a routine online encounter in which they experience no queries or problems with the transaction. The dimensions that those authors consider when evaluating the quality of service experienced by the customer are:

- efficiency;

- compliance;

- availability of the system; and

- confidentiality.

Moreover, the E-RecS-QUAL scale aims to measure the dimensions of quality that correspond to the recovery service; in other words, all the significant criteria of how the firm acts in a situation where the customer has queries or needs to solve some problem. This scale addresses issues such as response capability, compensation and contact.

The work of Posselt and Gerstner (2005) is also of interest, since it assesses the impact of the pre-sale and post-sale stages on online satisfaction. In the pre-sale stage, they use the following variables:

- ease of finding the desired product;

- the design and appeal of the website;

- the types of products available;

- clarity of product information;

- prices in comparison with those of other websites;

- delivery charges;

- delivery options;

- clarity of information; and

- the total cost of the purchase displayed before acceptance of order.

In the post-sale stage, they evaluate:

- the availability of the product;

- the possibility of knowing the status of the order;

- the delivery of the product within the expected time; 
IJQRM

27,2

124

- the delivery of the correct product as described;

- ease of access to the firm;

- courtesy of personnel; and

- complaints resolution.

At this point, we consider it appropriate to propose a two-stage model of the electronic purchase, in which the moment of the confirmation of the order defines the end of the first stage and the beginning of the second. More specifically, we distinguish a first phase of the electronic purchase, the pre-sale stage, and a second phase, the post-sale stage (see Figure 1). The details of the proposed scales for the two stages are presented in the following section.

\section{Dimensions and attributes of the two phases of the electronic purchase}

We now propose two scales of quality. The first scale contains the dimensions and attributes that measure quality in the pre-sale stage of the electronic purchase, while the second covers the dimensions and attributes measuring quality in the post-sale stage.

\section{Pre-sale stage}

The following dimensions represent the aspects of the service that the customer experiences in the online purchase encounter and refer to the stage prior to the purchase and during the closure of the purchase, including payment. These dimensions, which are also explained by specific attributes detailed in Table I, are design, information, security, adaption and offer.

Design. The web page becomes the meeting point between the customer and the firm. It represents the firm and replaces the figure of salesperson and the functions of the traditional tangible aspects of physical encounters. Yang et al. (2003) stress, customers must find it easy to browse because otherwise they will feel confused, find it difficult to use and reject it.

Figure 1.

Phases of electronic commerce

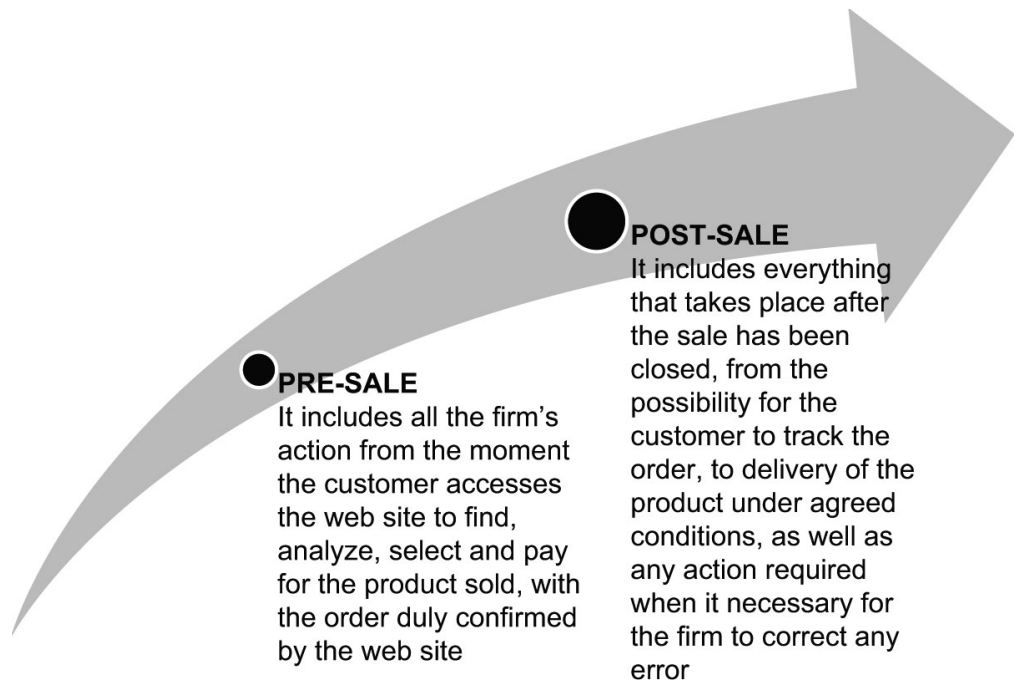




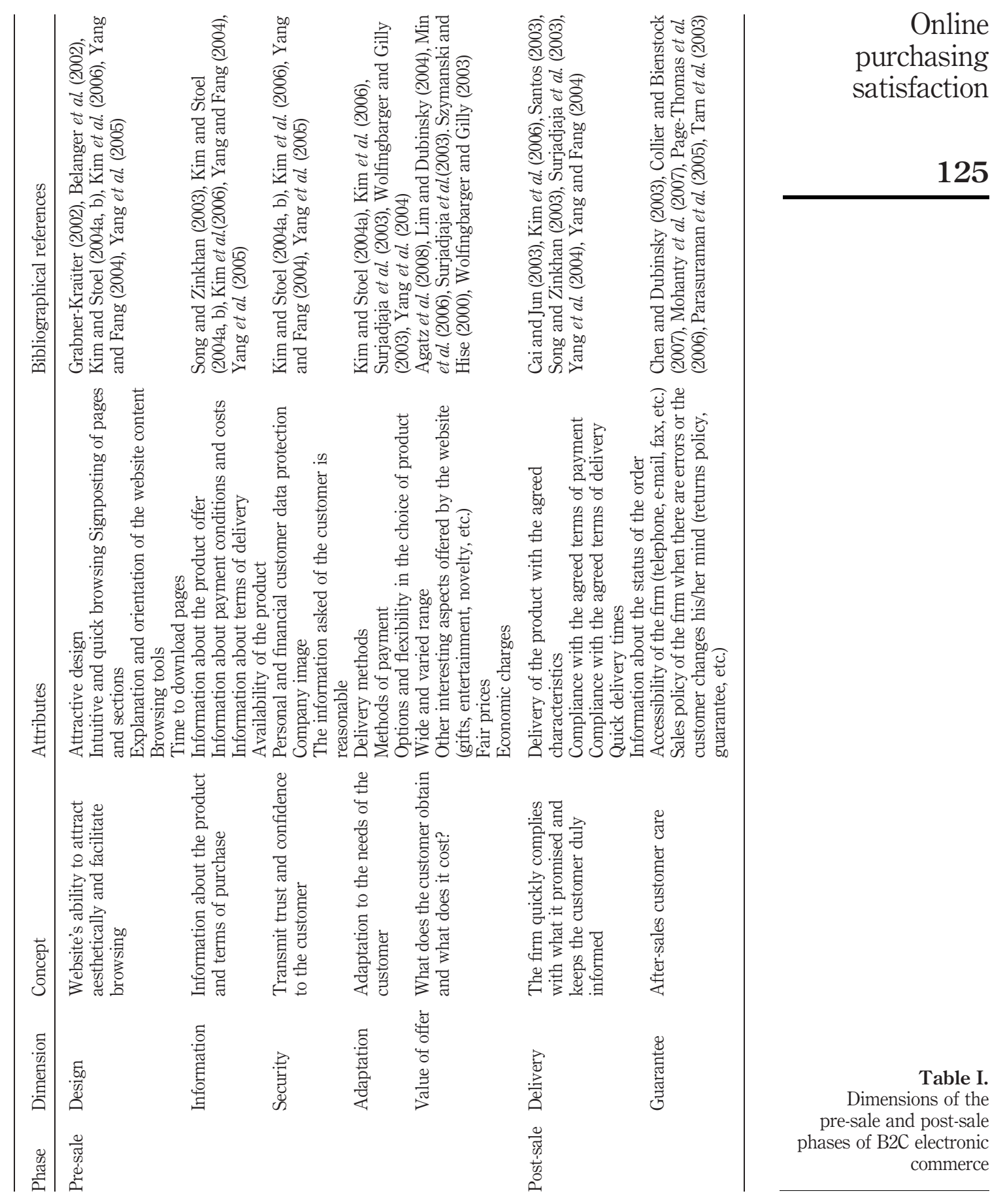


IJQRM

27,2

126

Information. The type of information that must be provided includes information about the prices to be paid, delivery charges, stock availability of product, delivery time and information about the products and services. All of that must be duly confirmed (by e-mail, for example) expressly stating the product ordered, quality and characteristics, total cost and terms of delivery (Mohanty et al., 2007; Page-Thomas et al., 2006; Collier and Bienstock, 2007; Kim et al., 2006; Kim and Lennon, 2004).

Security. The issues regarding the security of the online transaction that can heighten the perceived risk and lack of trust (Lee and Turban, 2001; Hoffman et al., 1988; Grabner-Kraüter and Kaluscha, 2003; Grabner-Kraüter, 2002). In this dimension, security is mainly related to the protection of the personal and financial data that the customer must provide in order to make the purchase.

Adaptation. This dimension represents the website offering the customer the possibility of choosing between different options and even participating in the design of the product/service. One of the most outstanding aspects is the range of options and modes in the offer of the service/product (Kim, 2002). This section also includes the range of delivery options (Feinberg et al., 2002) and the option of different forms of payment (credit or debit card, cash-on-delivery, bank transfer, etc.) (Kim, 2002; Kolesar and Galbraith, 2000).

Offer. This dimension covers the value of the website's offer, which results from the combination of the benefits obtained by the customer (product/service offered) against the economic costs of access to those benefits. As Rosenoer et al. (2000) indicate, the freedom from all physical restrictions that the firm on internet enjoys favours sales by enabling the firm to offer a potentially infinite variety of products and services. With regard to costs, these may include tariffs for delivery distance, taxes and postage and packing, etc. (Brynjolfsson and Smith, 2000).

Post-sale stage. This stage includes the dimensions comprising the customer's experience after closing the online purchase, which are delivery and guarantee. The attributes of these dimensions are shown in Table I.

Delivery. The dimension delivery includes the variables prompt delivery, delivery of products without errors or faults, compliance with the terms of delivery, compliance with the terms of payment and information about the status of the order (Rutner and Langley, 2000; Jackson et al., 1986; Ellram et al., 1999; Servera Francés et al., 2006; Kolesar and Galbraith, 2000; Xing and Grant, 2006).

Guarantee. It is very important that the firm establishes the necessary means for the customer to resolve any problems that may occur after closing the purchase. One way the firm can do this is to offer a returns policy and simple access to a representative of the firm who can address customer complaints and suggestions and show a real interest in listening to customers and attending to their requirements (Tarn et al., 2003; Smith, 2005).

\section{Research objectives and fieldwork}

This research has three basic objectives:

- Objective 1 - To determine the dimensionality of the scale of quality of the firm's actions in the pre-sale phase from the customer perspective. We propose the hypothesis (H1a) that the dimensions "design", "information", "security", "adaptation" and "value of the offer" form that scale. We also propose a second 
hypothesis $(H 1 b)$ that the dimensions of the pre-sale scale have a positive effect on the customer's disposition to repeat and disposition to recommend.

- Objective 2 - To determine the dimensionality of the scale of quality of the firm's actions in the post-sale phase, also from the customer perspective. We propose the hypothesis $(H 2 a)$ that the dimensions "delivery" and "guarantee" constitute that scale. As a second hypothesis $(H 2 b)$, we propose that the dimensions of the post-sale scale have a positive effect on the customer's disposition to repeat and disposition to recommend.

- Objective 3 - To analyse the impact of the firm's actions in the pre-sale phase on the customer's perception of the post-sale phase. We propose the hypothesis $(H 3)$ that the customer's perceptions of the pre-sale phase influence his/her perceptions in the post-sale phase.

The population of the study was defined as those lecturers at the University of Las Palmas de Gran Canaria (ULPGC) who had recently purchased on the internet. The choice of lecturer as the sample unit was considered suitable because it fits the profile of the average online purchaser in terms of education, income and age, as well as buying the products most commonly sold on internet, and guaranteeing the physical delivery of the product. The suitability of those characteristics stems from the fact that they fit not only the profile of the online purchaser and purchase pattern in Spain (AECEM, 2007, 2008; AIMC, 2007) but also international profiles (Li et al., 1999; Yoon et al., 2002; Miyazaki and Fernández, 2001). The population of lecturers at the ULPGC is approximately 1,600. After a telephone survey of 835 ULPGC lecturers, we established that the estimated population that fitted the desired characteristics comprised 452 individuals. At the end of the survey process, the final sample comprised 191 informants. With those data, the sample error was 5.4 per cent, with a reliability level of 95 per cent $(Z=1.96, p=q=50$ per cent).

The survey used a self-administered personal questionnaire to ask each respondent to answer various questions regarding his/her perception of the firm's actions - by means of a nine-point Likert type scale - in each of the variables in each of the theoretical scales proposed for each phase. Moreover, after we had reviewed the practices previously employed by other authors (Parasuraman et al., 2005; Yang et al., 2004; Jun et al., 2004; Parasuraman et al., 1988, 1994; Cronin and Taylor, 1992), the respondents were asked to give three scores (overall perceived quality, disposition to repeat the purchase experience and disposition to recommend the experience to others), also on a nine-point Likert-type scale.

\section{Results}

A principal components analysis with Varimax rotation was applied to the data base of each scale (see Tables II and III), with the criteria of the eigenvalue being 1 or higher in the choice of factors. As Tables II and III show, the KMO ratio (values between 0.7 and 0.8) are considered good and the Bartlett's sphericity test (the level of significance must be below 0.05 ) of both models confirmed the viability of the factor analysis. The data show:

- that the results of the factor analysis can be considered satisfactory, since they explain around 65 per cent of total explained variance; 
IJQRM

27,2

128

Information

Costs

Table II.

Principal components analysis for the pre-sale scale

\begin{tabular}{llcc}
\hline Dimension & Attributes & Communality & Factor load \\
\hline Design & Attractive design & 0.629 & 0.784 \\
& Easy browsing & 0.599 & 0.768 \\
& Signposting & 0.591 & 0.752 \\
& Tools & 0.657 & 0.784 \\
Information & Delivery information & 0.675 & 0.797 \\
& Order confirmation & 0.682 & 0.809 \\
Costs & Methods of delivery & 0.519 & 0.713 \\
& Prices & 0.706 & 0.837 \\
& Economic charges & 0.689 & 0.803
\end{tabular}

Notes: KMO: 0.749; Bartlett's sphericity test: 400.001 (0.000); scale reliability (Cronbach's $\alpha$ ): 0.726; total explained variance: 63.862 per cent
Table III.

Principal components analysis for the post-sale scale

\begin{tabular}{llcc}
\hline Dimension & Attributes & Communality & Factor load \\
\hline Delivery & Compliance with terms of payment & 0.585 & 0.748 \\
& Compliance with terms of delivery & 0.689 & 0.830 \\
Guarantee & Interest in claims and complaints & 0.718 & 0.806 \\
& Sales policy & 0.711 & 0.840 \\
& Accessibility & 0.605 & 0.778
\end{tabular}

Notes: KMO: 0.682; Bartlett's sphericity test: 171.603 (0.000); scale reliability (Cronbach's $\alpha$ ): 0.658; total explained variance: 66.149 per cent

- that the correlations between the factors and the different attributes, expressed by means of factor loads, are highly significant with levels exceeding 0.5 ; and

- that the proportion of explained variance of each attribute, expressed in terms of communality, is acceptable (above 0.5) (Hair et al., 1988).

With regard to the reliability of the scales, measured by Cronbach's $\alpha$, the level of reliability of the total scale for each model exceed the minimum recommended value of 0.7 (Nunally, 1978), although, in the case of exploratory scales, values of around 0.6 are acceptable (Flynn et al., 1990). The final result was a factor scale of three dimensions (design, information, costs) for the pre-sale phase and another of two dimensions for the post-sale phase (delivery and guarantee), with some modification to their initial configurations.

The second step was to apply a first-order confirmatory analysis. Firstly, a set of statistics was analysed (standardised CMIN, GFI, AGFI, RMSEA, PGFI, PNFI, NFI and $\mathrm{CFI}$ ) to assess the goodness of fit of each of the models. This enabled us to confirm the capability to reproduce the matrix of sample parameters, variances and covariances calculated for the sample. The figures in Tables IV and V show that the indicators of goodness of fit are acceptable (Bollen, 1989; Marsh et al., 1988; Hair et al., 1988).

Secondly, and regarding the compound reliability of the dimensions, which explains the degree of internal consistency of the attributes - in other words its capacity to represent the common latent variable (dimension) - the values are acceptable in both 


\begin{tabular}{|c|c|c|c|c|c|c|}
\hline Dimension & Attributes & $\begin{array}{l}\text { Standardised } \\
\text { regression } \\
\text { weights }\end{array}$ & $p$ & $\begin{array}{l}\text { Compound } \\
\text { reliability }\end{array}$ & $\begin{array}{c}\text { Extracted } \\
\text { variance }\end{array}$ & $\begin{array}{l}\text { purchasing } \\
\text { satisfaction }\end{array}$ \\
\hline Design & $\begin{array}{l}\text { Attractive design } \\
\text { Easy browsing } \\
\text { Signposting } \\
\text { Browsing tools }\end{array}$ & $\begin{array}{l}0.708 \\
0.650 \\
0.642 \\
0.771\end{array}$ & $\begin{array}{l}0.009 \\
0.005 \\
0.007 \\
0.005\end{array}$ & 0.79 & 0.48 & 129 \\
\hline Information & $\begin{array}{l}\text { Delivery } \\
\text { information } \\
\text { Order confirmation } \\
\text { Methods of delivery }\end{array}$ & $\begin{array}{l}0.754 \\
0.725 \\
0.513\end{array}$ & $\begin{array}{l}0.011 \\
0.014 \\
0.012\end{array}$ & 0.71 & 0.46 & \\
\hline Costs & $\begin{array}{l}\text { Fair prices } \\
\text { Economical } \\
\text { charges }\end{array}$ & $\begin{array}{l}0.508 \\
0.782\end{array}$ & $\begin{array}{l}0.015 \\
0.013\end{array}$ & 0.60 & 0.44 & \\
\hline
\end{tabular}

Notes: Indicators of goodness of fit: $\mathrm{CMIN}=25.738 ; p=0.367$; $\mathrm{CMIN} / \mathrm{DF}=1.072$; GFI $=0.970$; $\mathrm{AGFI}=0.944 ; \mathrm{RMSEA}=0.020 ; \mathrm{PNFI}=0.625 ; \mathrm{PGFI}=0.517$. Correlations between factors: 0.373 (information-costs), 0.426 (information-design), 0.276 (design-costs)

Table IV. Confirmatory analysis for the pre-sale scale

\begin{tabular}{llcccc}
\hline Dimension & Attributes & $\begin{array}{c}\text { Standardised } \\
\text { regression } \\
\text { weights }\end{array}$ & $p$ & $\begin{array}{c}\text { Compound } \\
\text { reliability }\end{array}$ & $\begin{array}{c}\text { Extracted } \\
\text { variance }\end{array}$ \\
\hline Delivery & Compliance with terms of payment & 0.604 & 0.016 & 0.44 & 0.30 \\
& Compliance with terms of delivery & 0.460 & 0.09 & & \\
Guarantee & Interest in claims and complaints & 0.819 & 0.019 & 0.76 & 0.51 \\
& Sales policy & 0.734 & 0.010 & & \\
& Accessibility & 0.572 & 0.005 & &
\end{tabular}

Notes: Indicators of goodness of fit: $\mathrm{CMIN}=4.978 ; p=0.290 ; \mathrm{CMIN} / \mathrm{DF}=1.244 ; \mathrm{GFI}=0.989$; $\mathrm{AGFI}=0.960 ; \mathrm{RMSEA}=0.036$; PNFI $=0.571 ; \mathrm{PGFI}=0.389$. Correlations between factors: 0.447 (delivery-guarantee)

Table V.

Confirmatory analysis for the post-sale scale

tables and for both scales, except for the dimension delivery, which displays a value below the recommended minimum of 0.60 (Bagozzi and Yi, 1988). The average extracted variance was also calculated: this indicates the overall level of variance in the indicators that is explained by the latent variable (Barrio García and Luque Martínez, 2000). According to Fornell and Larcker (1981), the average extracted variance must obtain values close to 0.50 , which means that 50 per cent of the variance of the construct is explained by its indicators. The average level of extracted variance exceeded that figure and therefore is acceptable although the dimension delivery displayed a lower level than recommended.

Thirdly, the convergent validity was analysed. This refers to the congruence (or high correlation) of the different indicators or attributes of a scale and indicates that the construct (dimension) is related to the observed variables or attributes in a theoretically adequate way (Bollen, 1989). As a minimum condition of convergent validity, the average extracted variance of the attributes associated with a given factor must exceed 
IJQRM

27,2

130
0.50 (Fornell and Larcker, 1981). Tables IV and V show that both scales meet that condition.

With regard to discriminant validity, this refers to the extent to which the measures of different concepts differ. In other words, discriminant validity is achieved if each attribute only estimates one factor - that is, the factors measure different things (Bagozzi et al., 1991). Tables IV and V show that the correlation between each pair of factors for each scale is below 0.80 , which indicates that the variables do not explain redundant information and that they represent different constructs (Bagozzi, 1994). Moreover, Fornell and Larcker (1981) state that discriminant validity is satisfied when the attributes of a dimension display a common variance above the squared correlation or variance shared between the dimension or construct and each of the other dimensions or constructs. It can be seen from Tables IV and V that, for all the models, the correlations between factors are below the square root of the average extracted variance of the associated factors.

In addition, the predictive validity of the two scales was compared. To that end, three regression analyses were applied, in which the respective dependent variables were overall quality, disposition to repeat and disposition to recommend while the independent variables were the factors in each model. As Tables VI and VII show, all

\begin{tabular}{lccc}
\hline Dimension & Standardised regression coefficient & $t$ & Significance \\
\hline Regression analysis with overall perceived quality (adjusted $R^{2}=0.288 ; \mathrm{F}(p)=26.581$ & $(0.000))$ \\
Design & 0.417 & 6.805 & 0.000 \\
Costs & 0.271 & 4.423 & 0.000 \\
Information & 0.228 & 3.725 & 0.000 \\
Regression analysis with disposition to recommend (adjusted $\left.R^{2}=0.148 ; F(p)=11.999(0.000)\right)$ \\
Information & 0.281 & 4.192 & 0.000 \\
Costs & 0.252 & 3.756 & 0.000 \\
Design & 0.139 & 2.076 & 0.039 \\
Regression analysis with disposition & to repeat (adjusted $R^{2}=0.151 ; F(p)=12.235(0.000)$ \\
Design & 0.300 & 4.491 & 0.000 \\
Information & 0.209 & 3.130 & 0.002 \\
Costs & 0.174 & 2.597 & 0.010 \\
& & & \\
\hline
\end{tabular}

Table VI.

Regression analysis for the pre-sale scale

\begin{tabular}{lccc}
\hline Dimension & Standardised regression coefficient & $t$ & Significance \\
\hline Regression analysis with overall perceived quality (adjusted $R^{2}=0.290 ; F(p)=39.823(0.000)$ ) \\
Guarantee & 0.445 & 7.275 & 0.000 \\
Delivery & 0.316 & 5.169 & 0.000 \\
Regression analysis with disposition & to recommend (adjusted $\left.R^{2}=0.203 ; F(p)=25.131(0.000)\right)$ \\
Delivery & 0.355 & 5.483 & 0.000 \\
Guarantee & 0.291 & 4.495 & 0.000 \\
Regression analysis with disposition & to repeat (adjusted $\left.R^{2}=0.271 ; F(p)=36.394(0.000)\right)$ & \\
Guarantee & 0.429 & 6.925 & 0.000 \\
Delivery & 0.309 & 4.984 & 0.000 \\
\hline
\end{tabular}

Table VII.

Regression analysis for the post-sale scale
Guarantee
Delivery

0.429
0.309
0.355

5.483

6.925
4.984 
the dimensions in both scales display positive relationships with the three variables under analysis (overall quality, disposition to repeat and disposition to recommend) and the validity of criteria and nomological validity are confirmed. It can be seen that the dimensions of the post-sale scale, especially the dimensions regarding behavioural intentions, have greater predictive value than those of the pre-sale scale.

On the basis of the above data, $H 1 a$ and $H 2 a$, regarding the dimensionality of the final scales, are partially accepted to the extent that the final scales represent a modification of the models originally proposed. $H 1 b$ and $H 2 b$ are accepted since the data confirm the predictive validity of the pre-sale and post-sale scales.

With the aim of achieving Objective 3, once the factor structure of the virtual pre sale and post-sale experience was known, we proceeded to identify the bivariate correlations between the variables constituting the pre-sale phase and those constituting the post-sale phase. The data obtained are shown in Table VIII and confirm H3, since they reveal the presence of significant correlations between the variables of the two-stage model.

The data displayed in Table VIII show that the variables of the dimension design (attractive design, browsing, signposting and browsing tools) do not display positive correlations with the variables of the dimension delivery (compliance with payment and delivery), but do with those of guarantee (interest in complaints, sales policy and accessibility). This seems logical since, if the customer finds the design complicated and, not favouring self-service, he/she will demand more of the dimension guarantee, in other words, greater support and orientation from the customer attention service (treatment of complaints, returns, etc.).

\begin{tabular}{|c|c|c|c|c|c|c|c|}
\hline Pre-sale & & $\begin{array}{l}\text { Interest in } \\
\text { complaints }\end{array}$ & $\begin{array}{l}\text { Sales } \\
\text { policy }\end{array}$ & Post-sale & $\begin{array}{l}\text { Deli } \\
\text { Compliance } \\
\text { with } \\
\text { payment }\end{array}$ & $\begin{array}{l}\text { very } \\
\text { Compliance } \\
\text { with } \\
\text { delivery }\end{array}$ & \\
\hline Design & $\begin{array}{l}\text { Attractive design } \\
\text { Browsing } \\
\text { Signposting } \\
\text { Browsing tools }\end{array}$ & $\begin{array}{c}0.296 \\
(0.000) \\
0.395 \\
(0.000) \\
0.272 \\
(0.000) \\
0.387 \\
(0.000)\end{array}$ & $\begin{array}{c}0.297 \\
(0.000) \\
0.311 \\
(0.000) \\
0.210 \\
(0.004) \\
0.332 \\
(0.000)\end{array}$ & $\begin{array}{c}0.288 \\
(0.000) \\
0.311 \\
(0.000) \\
0.235 \\
(0.001) \\
0.341 \\
(0.000)\end{array}$ & $\begin{array}{c}-0.122 \\
(0.093) \\
0.113 \\
(0.118) \\
0.133 \\
(0.067) \\
0.052 \\
(0.477)\end{array}$ & $\begin{array}{c}-0.024 \\
(0.742) \\
0.023 \\
(0.752) \\
0.097 \\
(0.180) \\
0.024 \\
(0.743)\end{array}$ & \\
\hline Information & $\begin{array}{l}\text { Delivery information } \\
\text { Order confirmation } \\
\text { Methods of delivery }\end{array}$ & $\begin{array}{c}0.292 \\
(0.000) \\
0.316 \\
(0.000) \\
0.292 \\
(0.000)\end{array}$ & $\begin{array}{c}0.213 \\
(0.003) \\
0.222 \\
(0.002) \\
0.184 \\
(0.011)\end{array}$ & $\begin{array}{c}0.102 \\
(0.158) \\
0.062 \\
(0.393) \\
0.055 \\
(0.452)\end{array}$ & $\begin{array}{c}0.203 \\
(0.005) \\
0.282 \\
(0.000) \\
0.018 \\
(0.803)\end{array}$ & $\begin{array}{c}0.550 \\
(0.000) \\
0.347 \\
(0.000) \\
0.294 \\
(0.000)\end{array}$ & \\
\hline Costs & $\begin{array}{l}\text { Fair prices } \\
\text { Economic charges }\end{array}$ & $\begin{array}{c}0.132 \\
(0.069) \\
0.202 \\
(0.005)\end{array}$ & $\begin{array}{c}0.130 \\
(0.072) \\
0.179 \\
(0.013)\end{array}$ & $\begin{array}{c}0.185 \\
(0.010) \\
0.164 \\
(0.023)\end{array}$ & $\begin{array}{c}0.065 \\
(0.371) \\
0.134 \\
(0.065)\end{array}$ & $\begin{array}{c}0.241 \\
(0.001) \\
0.238 \\
(0.000)\end{array}$ & $\begin{array}{l}\text { Table VIII. } \\
\text { Correlations between the } \\
\text { pre-sale phase and } \\
\text { post-sale phase }\end{array}$ \\
\hline
\end{tabular}

Online
purchasing satisfaction

131 
IJQRM

27,2

132

The variables of the dimension information (delivery information, order confirmation, and delivery methods) reveal a positive and significant correlation with the variables of the dimension guarantee (except accessibility) and dimension "delivery". This demonstrates that correct information in the pre-sale phase has a positive impact both on the dimension "guarantee" and on the dimension "delivery", since it reduces possible customer complaints and errors in payments and deliveries.

Moreover, the variables of the dimension costs (fair prices and economic charge) correlates with the variable "compliance with delivery" from the dimension delivery, which demonstrates that fair prices and reliable deliveries are factors that must be present in all electronic transactions if the survival of the firm is to be guaranteed.

The above relationships show that the organisation's actions in the pre-sale phase conditions, to a great extent, its actions in the post-sale phase. In other words, the post-sale actions are proof that the firm has played its role well in the pre-sale phase.

\section{Conclusion}

The academic literature on service quality has already addressed the influence of the firm's actions in the different stages of the service encounter. However, the study of the importance and implications of the different phases in the electronic purchase has not received the attention it merits. That issue is relevant to the actions of firms operating on the internet, especially those organisations that sell products that cannot be delivered digitally. In effect, from the moment that the firm controls the physical delivery, as occurs in most cases, there may be a discrepancy between what was promised and what occurs and is accomplished and resolved in the post-sale phase.

Based on the results, we can draw a series of conclusions that are summarized in Table IX, and on which we now comment. First of all, the dimensions design,

Table IX. Summary

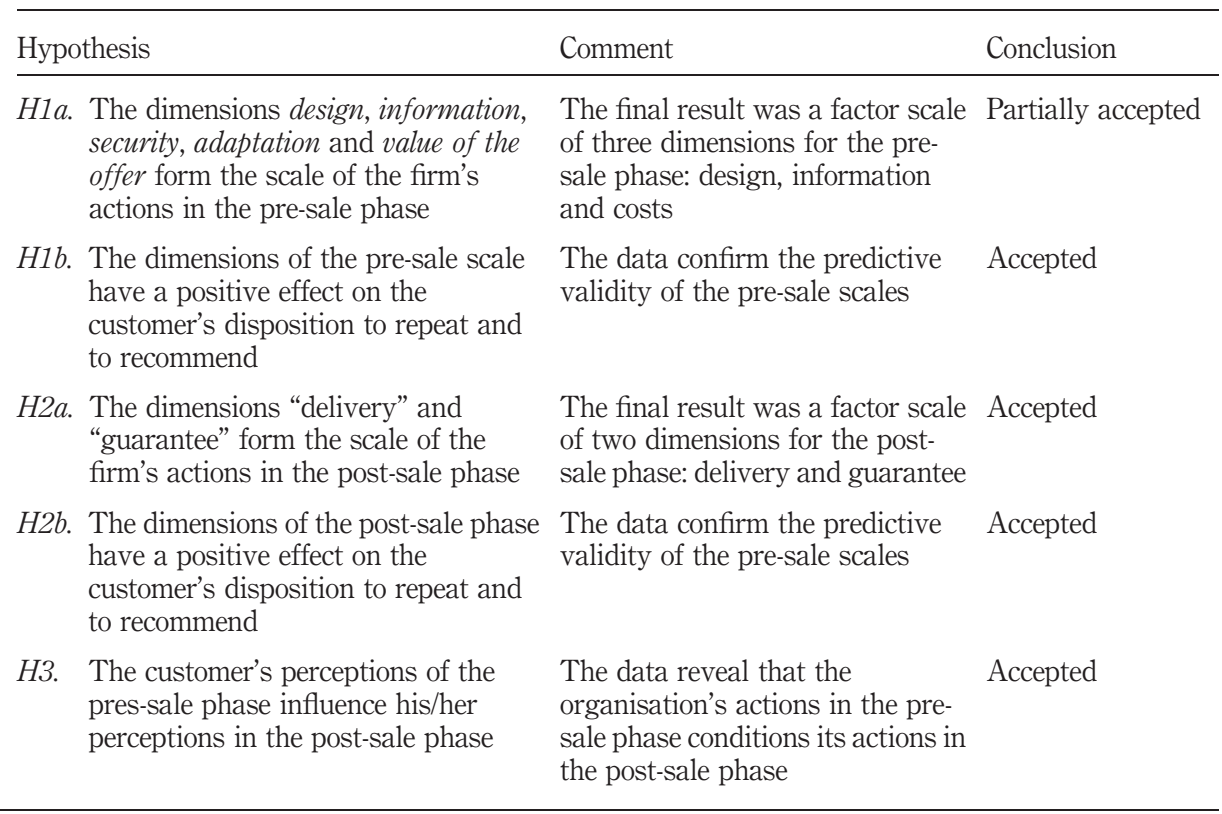

The final result was a factor scale Partially accepted sale phase: design, information costs

The data confirm the predictive Accepted of two dimensions for the postsale phase: delivery and guarantee

The data confirm the predictive Accepted have a positive effect on the customer's disposition to repeat and The customer's perceptions of the pres-sale phase influence his/her organisation's actions in the prethe post-sale phase 
information and costs constitute the factor structure of the pre-sale scale of quality. Secondly, the dimensions delivery and guarantee define the factor structure of the post-sale scale of quality. Our analyses show that both scales have a significant and positive impact on overall perceived quality and future behavioural intentions. However, the post-sale scale has a slightly greater effect on those constructs than the pre-sale scale. This reflects that the post-sale actions have greater influence on the success of the firm that sells online since those completed actions strengthen the perceptions of the firm's actions in the pre-sale phase. This situation demonstrates that the firm must exercise continuous control in order to avoid discrepancies between what was promised in the pre-sale phase and what was finally accomplished and resolved in the post-sale phase.

Moreover, there are significant correlations between the variables of the pre-sale scale and the post-sale scale. The reasons for that include the fact that any deficient action by the firm in the pre-sale phase has a negative effect on the post-sale phase. Also, the intensity and the characteristics of the actions in the post-sale phase depend to a great extent on the success of the pre-sale phase; this is accentuated in the electronic purchase due to its differential characteristics, namely the absence of the seller and the absence of physical premises.

Finally, apart from the need to replicate the research hypotheses with other data bases and so increase the goodness of fit of some statistical indicators, future lines of research and the actions of online retail websites should focus on relations with logistic agents and the improvement of customer care.

\section{References}

AECEM (2007), "Estudio sobre Comercio Electrónico B2C, 2007”, available at: www.aecem.org (accessed 11 December 2008).

AECEM (2008), "Estudio sobre Comercio Electrónico B2C, 2008", available at: www.aecem.org (accessed 11 December 2008).

AIMC (2007), "Navegantes en la Red, $10^{\mathrm{a}}$ encuesta AIMC a usuarios de Internet", available at: www.aimc.es/aimc.php (accessed 11 December 2008).

Agatz, N.A.H., Fleischmann, M. and van Nunen, J.A.E.E. (2008), "E-fulfillment and multi-channel distribution - a review", European Journal of Operational Research, Vol. 187 No. 2, pp. 339-56.

Bagozzi, R.P. and Yi, Y. (1988), "On the evaluation of structural equations models”, Journal of the Academy of Marketing Science, Vol. 16 No. 1, pp. 74-94.

Bagozzi, R.P., Yi, Y. and Phillips, L.W. (1991), “Assessing construct validity in organizational research”, Administrative Science Quarterly, Vol. 36, pp. 421-58.

Bagozzi, R. (1994), Structural Equation Model in Marketing Research. Basic Principles, Principles of Marketing Research, Blackwell, Oxford.

Barrio García, S. and Luque Martínez, T. (2000), “Análisis de ecuaciones estructurales”, in Luque Martínez, T. (Ed.), Técnicas de análisis de datos en investigación de mercados, Pirámide, Madrid, pp. 489-557.

Belanger, F., Hiller, J.S. and Smith, W.J. (2002), "Trustworthiness in electronic commerce: the role of privacy, security and site attributes", Journal of Strategic Information Systems, Vol. 11 Nos 3/4, pp. 245-70.

Bitner, M.J. (2001), "Service and the technology: opportunities and paradoxes”, Managing Service Quality, Vol. 11 No. 6, pp. 373-4.

\section{Online purchasing satisfaction}

133 
IJQRM

27,2

134

Bollen, K.A. (1989), Structural Equations with Latent Variables, Wiley, New York, NY.

Brynjolfsson, E. and Smith, M. (2000), "Frictionless commerce? A comparison of Internet and conventional retailers", Management Science, Vol. 46 No. 4, pp. 563-85.

Cai, S. and Jun, M. (2003), "Internet users' perceptions of online service quality: a comparison of online buyers and information searchers", Managing Service Quality, Vol. 13 No. 6, pp. 504-19.

Cao, Y. and Gruca, T.S. (2004), "The influence of pre- and post-purchase service on prices in the online book market”, Journal of Interactive Marketing, Vol. 18 No. 4, pp. 51-62.

Chen, S. and Chang, T. (2003), "A descriptive model of online shopping process: some empirical results”, International Journal of Service Industry Management, Vol. 14 No. 5, pp. 556-69.

Chen, Z. and Dubinsky, A.J. (2003), "Perceived customer value in e-commerce: a conceptual model and some preliminary findings", Psychology \& Marketing, Vol. 20 No. 4, pp. 323-47.

Collier, J.E. and Bienstock, C.C. (2007), "Measuring service quality in e-retailing", Journal of Service Research, Vol. 8 No. 3, pp. 260-75.

Constantinides, E. (2002), "The 4S web-marketing mix model”, Electronic Commerce Research and Applications, Vol. 1 No. 1, pp. 57-76.

Corbitt, B.J., Thanasankit, T. and Yi, H. (2003), "Trust and e-commerce: a study of consumer perceptions", Electronic Commerce Research and Applications, Vol. 2 No. 3, pp. 203-15.

Cronin, J.J. and Taylor, S.A. (1992), "Measuring service quality: a re-examination and extension", Journal of Marketing, Vol. 56, July, pp. 55-68.

Douglas, A., Muir, L. and Meehan, K. (2003), "E-quality in the e-services provision of legal practices", Managing Service Quality, Vol. 13 No. 8, pp. 483-91.

Ellram, L.M., La Londe, B.J. and Weber, M.M. (1999), "Retail logistics", International Journal of Physical Distribution \& Logistics, Vol. 29 Nos 7/8, pp. 477-94.

Feinberg, R.A., Kadam, R., Hokama, L. and Kim, I. (2002), "The state of electronic customer relationship management in retailing", International Journal of Retail of Distribution Management, Vol. 30 No. 10, pp. 470-81.

Flynn, B.B., Sakakibara, S., Schroeder, R.G., Bates, K.A. and Flynne, E.J. (1990), "Empirical research methods in operations management”, Journal of Operations Management, Vol. 9 No. 2, pp. 250-84.

Fornell, C. and Larcker, D.F. (1981), "Evaluating structural equation models with unobservable variables and measurement error", Journal of Marketing Research, Vol. 28, pp. 39-50.

Grabner-Kraüter, S. (2002), "The role of consumers' trust in online-shopping”, Journal of Business Ethics, Vol. 39, pp. 43-50.

Grabner-Kraüter, S. and Kaluscha, E.A. (2003), "Empirical research in on-line trust: a review and critical assessment”, International Journal Human-Computer Studies, Vol. 58, pp. 783-812.

Hair, J.F., Anderson, R.E., Tatham, R.L. and Black, W.C. (1988), Multivariate Data Analysis, 5th ed., Prentice-Hall, Upper Saddle River, NJ.

Hoffman, D.L., Novak, T.P. and Peralta, M. (1988), "Building consumer trust online", Communications of the ACM, Vol. 42, pp. 80-5.

Jackson, D.W., Keith, J.E. and Burdick, R.K. (1986), "Examining the relative importance of physical distribution service elements", Journal of Business Logistics, Vol. 7 No. 2, pp. 14-32.

Jiang, P. and Rosenbloom, B. (2005), "Customer intention to return online: price perception, attribute-level performance, and satisfaction unfolding over time", European Journal of Marketing, Vol. 39 Nos 1/2, pp. 150-74. 
Jun, M., Yang, Z. and Kim, D. (2004), "Customers' perceptions of online retailing service quality and their satisfaction", International Journal of Quality and Reliability Management, Vol. 21 No. 8, pp. 817-40.

Kim, Y.K. (2002), "Consumer value: an application to mall and internet shopping”, International Journal of Retail \& Distribution Management, Vol. 20 No. 2, pp. 595-602.

Kim, M. and Lennon, S.J. (2004), "Consumer response to product unavailability in online shopping", paper presented at the International Textiles and Apparel Association Annual Meeting, Portland, OR.

Kim, S. and Stoel, L. (2004a), "Dimensional hierarchy of retail website quality", Information \& Management, Vol. 41 No. 5, pp. 619-33.

Kim, S. and Stoel, L. (2004b), “Apparel retailers: website quality dimensions and satisfaction”, Journal of Retailing and Consumer Services, Vol. 11 No. 2, pp. 109-17.

Kim, M., Kim, J.H. and Lennon, S.J. (2006), "Online service attributes available on apparel retail web sites: an E-S-QUAL approach”, Managing Service Quality, Vol. 16 No. 1, pp. 51-77.

Kolesar, M.B. and Galbraith, R.W. (2000), "A services-marketing perspective on e-retailing: implications for e-retailers and directions for further research", Internet Research: Electronic Networking Applications and Policy, Vol. 10 No. 5, pp. 424-38.

Lee, M.K.O. and Turban, E. (2001), “A trust model for consumer internet shopping”, International Journal of Electronic Commerce, Vol. 6 No. 1, pp. 75-91.

Li, H., Kuo, C. and Russell, M. (1999), "The impact of perceived channel utilities, shopping orientations and demographics on the consumer's online shopping behaviour", Journal of Computer-Mediated Communication, Vol. 5 No. 2, pp. 1-20.

Lim, H. and Dubinsky, A.J. (2004), "Consumers' perception of e-shopping characteristics: an expectancy-value approach”, Journal of Services Marketing, Vol. 18 No. 7, pp. 500-13.

Marsh, H.W., Balla, J.R. and McDonald, R.P. (1988), "Goodness-of-fit indexes in confirmatory factor analysis: the effect of sample size”, Psychological Bulletin, Vol. 103 No. 3, pp. 391-410.

Min, H., Ko, H.J. and Ko, C.S. (2006), "A genetic algorithm approach to developing the multiechelon reverse logistics network for product returns", Omega, Vol. 34 No. 1, pp. 56-69.

Miyazaki, A.D. and Fernández, A. (2001), "Consumer perceptions of privacy and risks for online shopping”, Journal of Consumer Affairs, Vol. 35 No. 1, pp. 27-44.

Mohanty, R.P., Seth, D. and Mukadam, S. (2007), "Quality dimensions of e-commerce and their implications”, Total Quality Management \& Business Excellence, Vol. 18 No. 3, pp. 219-47.

Nunally, J.C. (1978), Psychometric Theory, McGraw-Hill, New York, NY.

O’Neill, M., Wright, C. and Fitz, F. (2001), "Quality evaluation in on-line service environments: an application of the importance-performance measurement technique", Managing Service Quality, Vol. 11 No. 6, pp. 402-17.

Page-Thomas, K., Moss, G., Chelly, D. and Yabin, S. (2006), "The provision of delivery information online: a missed opportunity", International Journal of Retail \& Distribution Management, Vol. 34 Nos 4/5, pp. 258-77.

Parasuraman, A., Zeithaml, V.A. and Berry, L.L. (1988), "SERVQUAL: a multiple-item scale for measuring consumer perceptions of service quality", Journal of Retailing, Vol. 64 No. 1, pp. 12-25.

Parasuraman, A., Zeithaml, V.A. and Berry, L.L. (1994), “Alternative scales for measuring service quality: a comparative assessment based on psychometric and diagnostic criteria”, Journal of Retailing, Vol. 70 No. 3, pp. 201-36. 
IJQRM

27,2

136
Parasuraman, A., Zeithaml, V.A. and Malhotra, A. (2005), "E-S-QUAL multiple-item scale for assessing electronic service quality”, Journal of Service Research, Vol. 7 No. 3, pp. 213-33.

Posselt, T. and Gerstner, E. (2005), "Pre-sale vs. post-sale e-satisfaction: impact on repurchase intention and overall satisfaction”, Journal of Interactive Marketing, Vol. 19 No. 9, pp. 35-47.

Rosenoer, J., Armstrong, D. and Gates, J.R. (2000), La empresa clickeable, Granica, Barcelona.

Rutner, S.M. and Langley, C.J. (2000), "Logistics value: definition, process and measurement", International Journal of Logistics Management, Vol. 1 No. 2, pp. 73-82.

Santos, J. (2003), "E-service quality: a model of virtual service quality dimensions", Managing Service Quality, Vol. 13 No. 3, pp. 233-46.

Servera Francés, D., Fuentes Blanco, M., Gil Saura, I. and Berenguer Contrí, G. (2006), "La calidad del servicio logístico y su influencia en la lealtad. Un análisis del papel de las TIC", paper presented at the XVI Congreso Nacional de ACEDE, Valencia, September.

Smith, A. (2005), "Reverse logistics programs: gauging their effects on CRM and online behaviour", The Journal of Information and Knowledge management systems, Vol. 35 No. 3, pp. 166-81.

Song, J.H. and Zinkhan, G.M. (2003), "Features of web site design, perceptions of web site quality, and patronage behaviour", ACME 2003 Proceedings, Houston, TX, pp. 106-14.

Surjadjaja, H., Ghosh, S. and Antony, J. (2003), "Determining and assessing the determinants of e-service operations”, Managing Service Quality, Vol. 13 No. 1, pp. 39-53.

Szymanski, D.M. and Hise, R.T. (2000), "E-satisfaction: an initial examination", Journal of Retailing, Vol. 76 No. 3, pp. 309-22.

Tarn, J.M., Razi, M.A., Wen, H.J. and Perez, A.A. Jr (2003), "E-fulfillment: the strategy and operational requirements", Logistics Information Management, Vol. 16 No. 5, pp. 350-62.

Wolfingbarger, M. and Gilly, M. (2003), "eTailQ: dimensionalizing, measuring and predicting etail quality”, Journal of Retailing, Vol. 79, pp. 183-98.

Xing, Y. and Grant, D.G. (2006), "Developing a framework for measuring physical distribution service quality of multi-channel and 'pure player' internet retailers", International Journal of Retail \& Distribution Management, Vol. 34 Nos 4/5, pp. 278-89.

Yang, D., Lo, J. and Weng, J. (2003), “The study on perceived risk and convenience degree factors for affecting internet transaction intention", paper presented at the Hawaii International Conference on Business, Honolulu, HI, 18-21 June.

Yang, Z. and Fang, X. (2004), "Online service quality dimensions and their relationships with satisfaction: a content analysis of customer reviews of securities brokerage services", International Journal of Service Industry Management, Vol. 15 No. 3, pp. 302-26.

Yang, Z., Jun, M. and Peterson, R.T. (2004), "Measuring customer perceived online service quality”, International Journal of Operations \& Production Management, Vol. 24 No. 11, pp. 1149-74.

Yang, Z., Cai, A., Zhou, K. and Zhou, N. (2005), "Development and validation of an instrument to measure user perceived service quality of information presenting web portals", Information \& Management, Vol. 42 No. 4, pp. 575-89.

Yoon, D., Cropp, F. and Cameron, G. (2002), "Building relationships with portal users: the interplay of motivation and relational factors", Journal of Interactive Advertising, Vol. 3 No. 1. 


\section{Further reading}

Koster, R.B.M. (2002), “The logistics behind the enter click”, in Klose, A., Gracia Speranza, M. and Van Wassenhove, L.N. (Eds), Quantitative Approaches to Distribution Logistics and Supply Chain Management, Springer, Berlin, pp. 131-48.

Trocchia, P.J. and Janda, S. (2003), "How do consumers evaluate internet retail service quality?", Journal of Services Marketing, Vol. 17 No. 3, pp. 243-53.

\section{Online purchasing satisfaction}

137

\section{About the authors}

Lucía Melián Alzola has a Higher Degree in Economics and Business Sciences and has a PhD from the University of Las Palmas de Gran Canaria, where she is currently teaches. She is the author of many articles and research works in the field of quality and has published in scientific journals such as International Journal of Quality \& Reliability Management, The Services Industries Journal, Quality Management Journal, European Journal of Marketing, Managing Service Quality and Revista Europea de Dirección y Economía de la Empresa. Moreover, she has received awards for different works on quality management on the internet. Lucía Melián Alzola is the corresponding author and can be contacted at: lmelian@dede.ulpgc.es

Víctor Padrón Robaina has a PhD in Economics and Business Sciences from the University of Las Palmas de Gran Canaria (ULPGC). He is currently a Senior Lecturer in the Department of Economics and Business Management at the ULPGC. He is the author of numerous articles and research works in the areas of quality and electronic commerce that have been published in many different scientific journals, including Quality \& Reliability Management, Quality Management Journal, The Service Industries Journal, International Journal of Service Technology and Management, and International Journal of Management Review.

To purchase reprints of this article please e-mail: reprints@emeraldinsight.com Or visit our web site for further details: www.emeraldinsight.com/reprints 